\title{
Trends of Arbekacin-resistant MRSA Strains in Japanese Hospitals (1979 to 2000)
}

\author{
Naofumi Tsuchizaki, Keiko Ishino, Fumiko Saito, Jun Ishikawa, Mutsuyasu Nakajima, \\ Kunimoto Hotta
}

Received: February 10, 2006 / Accepted: April 7, 2006

(C) Japan Antibiotics Research Association

\begin{abstract}
A total of 472 clinical strains of methicillinresistant Staphylococcus aureus (MRSA) isolated in Japan between 1979 and 2000 were investigated for resistance to 8 aminoglycosides, 4 aminoglycoside-modifying enzyme gene profiles, and $A l u \mathrm{I}$-restriction fragment length polymorphism of the coagulase gene determined by polymerase chain reaction assay. The majority of MRSA strains tested belonged to 4 groups based on coa-RFLP: L21, L22, L31, and M22. About 90\% of recent isolates belonged to type L21, indicating the spread of a specific type of MRSA in Japan. Of the type L21 strains, 41.9\% included the $\operatorname{aac}\left(6^{\prime}\right) / \operatorname{aph}\left(2^{\prime \prime}\right)$ gene, which was one of the risk factors of arbekacin (ABK) resistance, but only 5.5\% were resistant to $\mathrm{ABK}$. In contrast, all of the type M22 strains carried $\operatorname{aac}\left(6^{\prime}\right) / \operatorname{aph}\left(2^{\prime \prime}\right)$ and $70.1 \%$ showed ABK resistance. Among the other types, less than $20 \%$ of strains showed $\mathrm{ABK}$ resistance. These results suggested that $\mathrm{ABK}$ has maintained potent activity. If the predominance of type L21 continues, there will be no progression to ABK resistance in MRSA. However, it may be necessary to monitor the trends in type M22 continuously.
\end{abstract}

K. Ishino (Corresponding author), F. Saito, J. Ishikawa, K. Hotta: Department of Bioactive Molecules, National Institute of Infectious Diseases, 1-23-1 Toyama, Shinjuku, Tokyo 162-8640, Japan, E-mail: ishino@nih.go.jp

N. Tsuchizaki: Japan Microbiological Clinic, Co., Ltd., 5-17-1, Okada, Atsugi, Kanagawa 243-0021, Japan

M. Nakajima: Department of Applied Biological Science, College of Bioresource Sciences, Nihon University, 1866 Kameino, Fujisawa, Kanagawa 252-8510, Japan
Keywords MRSA, arbekacin resistance, coa-RFLP typing

\section{Introduction}

The use of antibiotics is essential in the therapy of infectious diseases, but resistant bacteria have been emerging rapidly. Methicillin-resistant Staphylococcus aureus (MRSA) is a major cause of nosocomial infection, and has acquired resistance to a wide range of antibiotics, including aminoglycosides (AGs). As observed in a number of clinical isolates, enzymatic modification is a common mechanism of resistance to AG. AG-modifying enzymes (AMEs) can be divided into three classes based on the reaction catalyzed: i.e., phosphorylation or adenylylation of a hydroxyl group and acetylation of an amino group [1,2]. The enzymes differ in their substrate specificity and are named according to the site that they modify on the antibiotic molecule. In MRSA, five AME-encoding genes, $\operatorname{aph}\left(3^{\prime}\right), \operatorname{aad}\left(4^{\prime}, 4^{\prime \prime}\right), \operatorname{aad}(6), \operatorname{aph}(9)$, and $\operatorname{aac}\left(6^{\prime}\right) / \operatorname{aph}\left(2^{\prime \prime}\right)$, have been reported [3]. In particular, the bifunctional enzyme, $\operatorname{AAC}\left(6^{\prime}\right) / \operatorname{APH}\left(2^{\prime \prime}\right)$, is of therapeutic importance because it is able to modify arbekacin (ABK), which is an anti-MRSA drug used in Japan [4, 5].

Recently, we reported the distinctive features of $\mathrm{ABK}$ against modification by AMEs [6]. Although ABK can be acetylated by AG acetyltransferases (AACs), acetylated products retain substantial antibiotic activity to inhibit bacterial growth. This suggested that the emergence of ABK resistance in MRSA would not progress as rapidly as observed for other antibiotics [7]. In the present study, we examined resistance of clinically isolated MRSA strains to AGs, including ABK, in Japan between 1979 and 2000 to 
understand current trends and to predict future trends of ABK-resistant MRSA strains.

\section{Materials and Methods}

\section{Bacterial Strains}

A total of 472 MRSA isolates were collected from various clinical sources between 1979 and 2000 in different parts of Japan [8 10]. All strains were identified as MRSA based on detection of the mecA gene.

\section{Determination of Coagulase Gene (coa)-restriction Fragment Length Polymorphism (RFLP) Type}

The 3 '-end region of coa was amplified using the primers coaF (ATAGAGATGCTGGTACAGG) and coaR (GCTTCCGATTGTTCGATGC) [11]. The polymelase chain reaction (PCR) mixtures $(20 \mu \mathrm{l})$ consisted of $1 \times \mathrm{PCR}$ buffer, $0.2 \mathrm{mM}$ each dNTP, $1.0 \mathrm{mM} \mathrm{MgSO}_{4}, 0.4$ units of KOD -Plus- DNA polymerase (Toyobo, Osaka, Japan), and $0.3 \mu \mathrm{M}$ each primer. A microscopic amount of each bacterial colony was transferred to these reaction mixtures with the tip of a toothpick from the surfaces of colonies on agar plates as described previously [12]. PCR was performed using a DNA Engine PTC-200 (MJ Research, Waltham, MA) for a total of 30 cycles under the following conditions: denaturation at $95^{\circ} \mathrm{C}$ for 30 seconds, annealing at $60^{\circ} \mathrm{C}$ for 30 seconds, and extension at $68^{\circ} \mathrm{C}$ for 1 minute. PCR products were analyzed by $2.2 \%$ agarose gel electrophoresis in TBE buffer. For restriction analysis, the PCR products were digested with AluI (Toyobo).

\section{Determination of AME Gene Profile}

Determination of the AME gene profile was performed by a 5-plex colony direct PCR method using the following primers: mecA: mecAP1 TGTCCGTAACCTGAATCAGC and mecAP2 TGCTATCCACCCTCAAACAG; $a a c\left(6^{\prime}\right) /$ $\operatorname{aph}\left(2^{\prime \prime}\right):$ ac/phP1 TACAGAGCCTTGGGAAGATG and ac/phP2C CATTTGTGGCATTATCATCATATC; aph(3')III: aphA3P1 CTGATCGAAAAATACCGCTGC and aphA3P2 TCATACTCTTCCGAGCAAAGG; $\operatorname{aad}\left(4^{\prime}, 4^{\prime \prime}\right)$ : aadCP1 CTGCTAAATCGGTAGAAGC and aadCP2 CAGACCAATCAACATGGCACC. Primers were designed to obtain PCR products of the following sizes: mecA, $519 \mathrm{bp} ; \operatorname{aac}\left(6^{\prime}\right) / \operatorname{aph}\left(2^{\prime \prime}\right), \quad 407 \mathrm{bp} ; \operatorname{aph}\left(3^{\prime}\right)-I I I, \quad 269 \mathrm{bp}$; $\operatorname{aad}\left(4^{\prime}, 4^{\prime \prime}\right), 174 \mathrm{bp}$. PCR was performed in the mixture described above for a total of 30 cycles as follows: denaturation at $95^{\circ} \mathrm{C}$ for 30 seconds, annealing at $50^{\circ} \mathrm{C}$ for 30 seconds, and extension at $68^{\circ} \mathrm{C}$ for 1 minute. PCR products were analyzed by $2.2 \%$ agarose gel electrophoresis in TBE buffer.

\section{Determination of AG Antibiotic Resistance}

MRSA strains were examined for resistance against kanamycin (KM), dibekacin (DKB), amikacin (AMK), arbekacin (ABK), gentamicin (GM), sisomicin (SISO), isepamicin (ISP), and netilmicin (NTL). Resistance levels were determined by the agar dilution method using Mueller Hinton II medium (Becton Dickinson, Franklin Lakes, NJ) containing $\mathrm{AG}$ at concentrations of 0 to $100 \mu \mathrm{g} / \mathrm{ml}$ as described previously [6].

\section{Results and Discussion}

We investigated the incidence of AG-resistant MRSA strains isolated in four periods: 1979 1983, 1986 1990, 1997 1999, and 2000. As shown in Fig. 1a, more than $80 \%$ of strains were resistant to KM, DKB, and AMK through all four periods. These resistant phenotypes seemed to be conferred mainly by $\operatorname{aac}\left(6^{\prime}\right) / \operatorname{aph}\left(2^{\prime \prime}\right)$ genes in the early period and by $\operatorname{aad}\left(4^{\prime}, 4^{\prime \prime}\right)$ genes in more recent periods (Fig. 1b). The recent increase in ISP-resistant strains can also be explained by the increase in incidence of strains carrying $\operatorname{aad}\left(4^{\prime}, 4^{\prime \prime}\right)$ instead of $\operatorname{aac}\left(6^{\prime}\right) / \operatorname{aph}\left(2^{\prime \prime}\right)$, because ISP is also a substrate of $\operatorname{AAD}\left(4^{\prime}, 4^{\prime \prime}\right)$ as well as $\operatorname{AAC}\left(6^{\prime}\right) / \operatorname{APH}\left(2^{\prime \prime}\right)[1,13]$. The incidence of strains resistant to GM, SISO, and NTL decreased markedly from $>80 \%$ to about $40 \%$ in recent periods. The decreases in these resistant strains were parallel to the decrease in $\operatorname{aac}\left(6^{\prime}\right) /$ aph $\left(2^{\prime \prime}\right)$ genes, suggesting that the observed resistances were conferred by $\mathrm{AAC}\left(6^{\prime}\right) / \mathrm{APH}\left(2^{\prime \prime}\right)$. In contrast, $\mathrm{ABK}-$ resistant strains remained at a low level throughout all four periods. The lack of an increase in the prevalence of ABKresistant strains may suggest the effectiveness of $A B K$ as an anti-MRSA drug.

Recently, it has been shown that RFLP analysis for the coa of S. aureus is useful for typing of MRSA $[14,15]$. We carried out coa-RFLP analysis and classified the 472 strains tested into 16 types with original names according to band patterns, details of which will be described elsewhere. The results clearly demonstrated the prevalence of two coaRFLP types (Fig. 1c). Type L22 was predominant in the period 1979 1983, but then disappeared rapidly. In recent periods, the majority of MRSA strains belonged to a single coa-RFLP type, L21, which accounted for $90.7 \%$ and $87.4 \%$ of isolates in periods $1996 \sim 1999$ and 2000, respectively. There were no remarkable changes in prevalence of other coa-RFLP types.

Each coa-RFLP type seems to have, to some extent, a characteristic resistance profile (Table 1). In types L22, L31, and M22, over $80 \%$ of strains showed resistance to GM, especially type M22 (100\%). In contrast, only $41.9 \%$ 
a

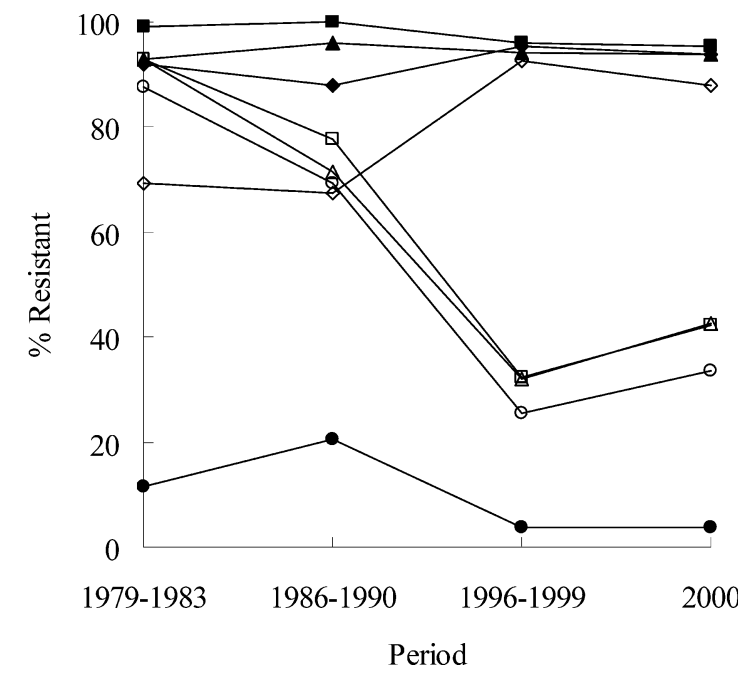

b

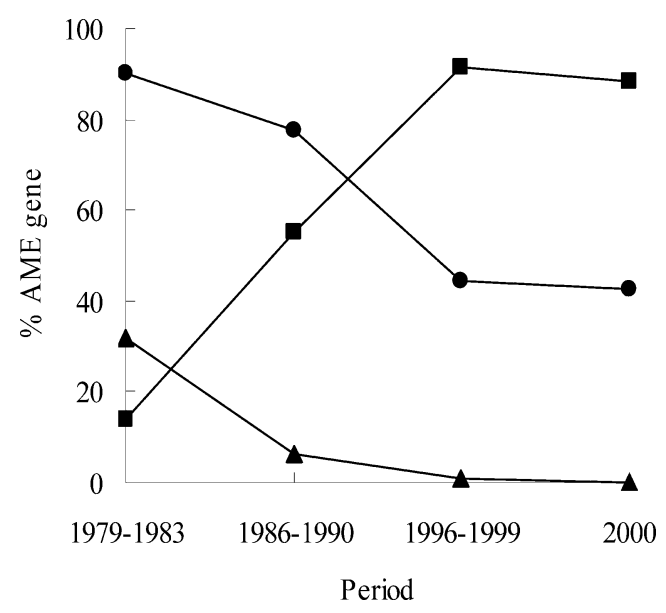

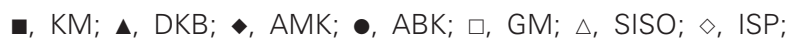
O, NTL.

C
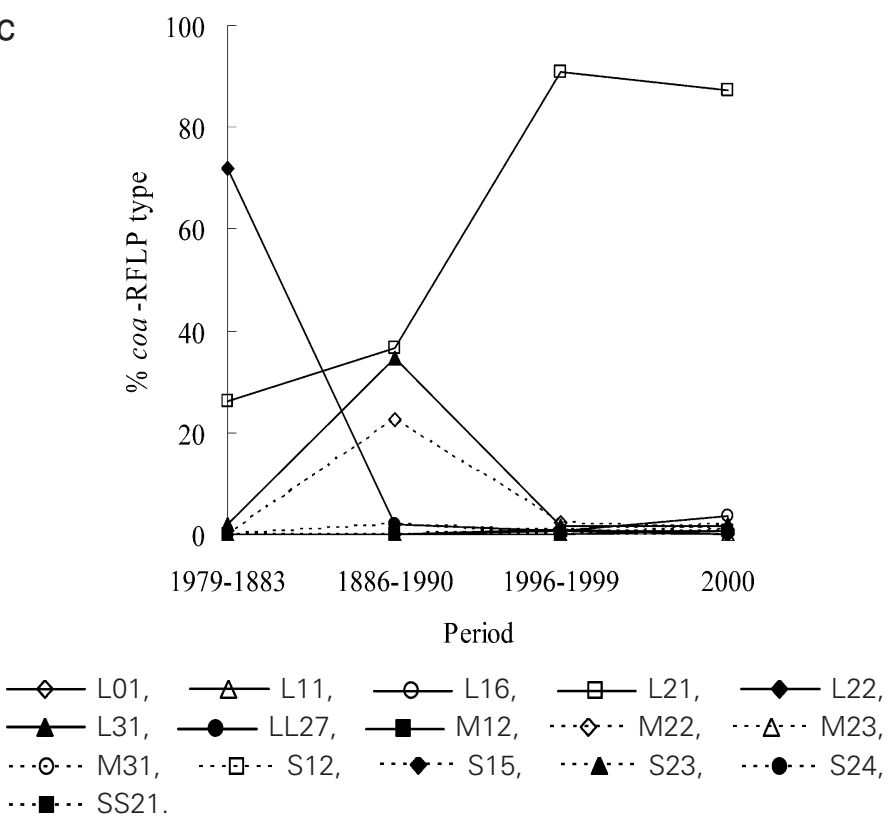

Fig. 1 Temporal shifts in the prevalence of MRSA strains analyzed for (a) AG resistance, (b) AME genes, and (c) coa-RFLP types.

of type L21 strains showed GM resistance. This was completely consistent with the incidence of the $\operatorname{aac}\left(6^{\prime}\right) / \operatorname{aph}\left(2^{\prime \prime}\right)$ gene in type L21. Similarly, resistance to SISO and NTL of type L21 strains can be explained by the presence or absence of the $\operatorname{aac}\left(6^{\prime}\right) / \operatorname{aph}\left(2^{\prime \prime}\right)$ gene. On the other hand, most of the type L21 strains were resistant to $\mathrm{KM}, \mathrm{DKB}, \mathrm{AMK}$, and ISP, reflecting the observation that over $90 \%$ of type L21 strains possessed the $\operatorname{aad}\left(4^{\prime}, 4^{\prime \prime}\right)$ gene. No strains carrying the $\operatorname{aph}\left(3^{\prime}\right)$ gene were found in type L21.

Types M22 and M31 were distinguished from other types by a high incidence of ABK-resistant strains. Types M22 and M31 showed $70 \%$ and $66.7 \%$ resistant strains, respectively, whereas less than $20 \%$ of strains of other types showed $\mathrm{ABK}$ resistance. In particular, less than $10 \%$ of strains belonging to types L21 and L31 showed ABK resistance. 
Table 1 Distribution of AME genes and AG resistance in each coa-RFLP type

\begin{tabular}{|c|c|c|c|c|c|c|c|c|c|c|c|c|}
\hline \multirow{2}{*}{ Type } & \multirow{2}{*}{$\begin{array}{l}\text { Number } \\
\text { of strain }\end{array}$} & \multicolumn{3}{|c|}{$\%$ of AME genes } & \multicolumn{8}{|c|}{$\%$ of resistant strains* } \\
\hline & & $\begin{array}{l}\operatorname{aac}\left(6^{\prime}\right) / \\
\operatorname{aph}\left(2^{\prime \prime}\right)\end{array}$ & $\operatorname{aad}\left(4^{\prime}, 4^{\prime \prime}\right)$ & $\operatorname{aph}\left(3^{\prime}\right)$ & $\mathrm{KM}$ & DKB & AMK & ABK & $\mathrm{GM}$ & SISO & ISP & NTL \\
\hline L21 & 363 & 41.9 & 91.2 & 0 & 96.1 & 92.8 & 95.9 & 5.5 & 41.9 & 42.2 & 92.0 & 37.5 \\
\hline L22 & 38 & 89.4 & 7.9 & 47.4 & 97.4 & 89.5 & 86.8 & 13.2 & 89.5 & 89.5 & 76.3 & 73.7 \\
\hline L31 & 24 & 83.3 & 8.3 & 12.5 & 95.8 & 91.7 & 66.7 & 0 & 83.3 & 75 & 29.2 & 66.7 \\
\hline M22 & 17 & 100 & 70.6 & 0 & 100 & 100 & 94.1 & 70.1 & 100 & 100 & 76.5 & 88.2 \\
\hline L16 & 8 & 100 & 75 & 0 & 100 & 100 & 100 & 12.5 & 100 & 100 & 100 & 75 \\
\hline S23 & 6 & 83.3 & 100 & 0 & 100 & 100 & 100 & 0 & 83.3 & 83.3 & 66.7 & 66.7 \\
\hline M23 & 3 & 0 & 100 & 0 & 100 & 100 & 100 & 0 & 0 & 0 & 100 & 0 \\
\hline M31 & 3 & 100 & 33.3 & 0 & 100 & 100 & 66.7 & 66.7 & 100 & 100 & 66.7 & 66.7 \\
\hline L01 & 2 & 0 & 0 & 0 & 0 & 0 & 0 & 0 & 0 & 0 & 0 & 0 \\
\hline L11 & 2 & 100 & 100 & 0 & 100 & 100 & 100 & 0 & 100 & 100 & 100.0 & 100 \\
\hline LL27 & 1 & 100 & 0 & 0 & 100 & 100 & 0 & 0 & 100 & 0 & 0 & 0 \\
\hline M12 & 1 & 0 & 100 & 0 & 0 & 0 & 0 & 0 & 0 & 0 & 0 & 0 \\
\hline $\mathrm{S} 12$ & 1 & 100 & 100 & 0 & 100 & 100 & 100 & 0 & 100 & 100 & 100 & 0 \\
\hline S15 & 1 & 0 & 0 & 0 & 0 & 0 & 0 & 0 & 0 & 0 & 0 & 0 \\
\hline S24 & 1 & 100 & 0 & 0 & 100 & 0 & 0 & 0 & 100 & 0 & 0 & 0 \\
\hline SS21 & 1 & 100 & 100 & 0 & 100 & 100 & 100 & 0 & 100 & 100 & 100 & 0 \\
\hline
\end{tabular}

* The cut-off AGs concentration is $>6.25 \mu \mathrm{g} / \mathrm{ml}$.

\section{Conclusions}

We found that the majority of MRSA strains tested belonged to 4 types based on coa-RFLP: L21, L22, L31, and M22. Although the prevalence of these types differed from each other over the four periods examined, in recent periods, about $90 \%$ of strains belonged to type L21. This indicated the spread of a specific type of MRSA in Japan. Similar results have been reported using a different approach [16]. Although all strains of type M22 possessed $\operatorname{aac}\left(6^{\prime}\right) / \operatorname{aph}\left(2^{\prime \prime}\right)$ gene and $70.1 \%$ were resistant to $\mathrm{ABK}$, only $5.5 \%$ of type L21 strains were resistant to ABK despite that about half of them carried the $\operatorname{aac}\left(6^{\prime}\right) / \operatorname{aph}\left(2^{\prime \prime}\right)$ gene. Our preliminary experiments showed that there were no nucleotide sequence differences in both coding region and upstream region of $\operatorname{aac}\left(6^{\prime}\right) / \operatorname{aph}\left(2^{\prime \prime}\right)$ gene between ABK-resistant and several ABK-susceptible strains belonging to type L21 (unpublished data). These observations might suggest the lack of unknown factor(s) achieving ABK resistance by the $\operatorname{aac}\left(6^{\prime}\right) / \operatorname{aph}\left(2^{\prime \prime}\right)$ gene in type L21 strains. In this context, if the predominance of type $\mathrm{L} 21$ continues, it will not progress to $\mathrm{ABK}$ resistance in MRSA. However, it may be necessary to monitor the trend of type M22 continuously, because of the high incidences of both ABK resistance and $\operatorname{aac}\left(6^{\prime}\right) / \operatorname{aph}\left(2^{\prime \prime}\right)$ gene in this type.
Acknowledgments We are grateful to Drs. T. Okubo, S. Kondo, K. Kikuchi, Y. Arakawa, and A. Wada for MRSA strains, to Mr. H. Matsumoto for technical assistance, and to Dr. Y. Uehara for helpful discussion. This work was supported in part by a Grant-inAid for Scientific Research from the Ministry of Education, Science, Sports, and Culture (no. 13770143) and by a grant from the Japan Health Sciences Foundation (no. KH53117).

\section{References}

1. Shaw KJ, Rather PN, Hare RS, Miller GH. Molecular genetics of aminoglycoside resistance genes and familial relationships of the aminoglycoside-modifying enzymes. Microbiol Rev 57: 138-163 (1993)

2. Davies J, Wright GD. Bacterial resistance to aminoglycoside antibiotics. Trends Microbiol 5: 234-240 (1997)

3. Vakulenko SB, Mobashery S. Versatility of aminoglycosides and prospects for their future. Clin Microbiol Rev 16: 430-450 (2003)

4. Kondo S, Tamura A, Gomi S, Ikeda Y, Takeuchi T, Mitsuhashi S. Structures of enzymatically modified products of arbekacin by methicillin-resistant Staphylococcus aureus. J Antibiot 46: 310-315 (1993)

5. Ishino K, Ishikawa J, Ikeda Y, Hotta K. Characterization of a bifunctional aminoglycoside-modifying enzyme with novel substrate specificity and its gene from a clinical isolate of methicillin-resistant Staphylococcus aureus with high 
arbekacin resistance. J Antibiot 57: 679-686 (2004)

6. Hotta K, Sunada A, Ikeda Y, Kondo S. Double stage activity in aminoglycoside antibiotics. J. Antibiot 53: 1168-1174 (2000)

7. Kondo S, Hotta K. Semisynthetic aminoglycoside antibiotics: Development and enzymatic modifications. J Infect Chemother 5: 1-9 (1999)

8. Kondo S, Ikeda Y, Hattori S, Hamada M, Takeuchi T. Susceptibility of methicillin-resistant Staphylococcus aureus to various antibiotics. Classification by aminoglycosidemodifying enzymes and antibiotics active against MRSA. Jpn J Antibiot 44: 1211-1215 (1991)

9. Ike Y, Arakawa Y, Ma X, Tatewaki K, Nagasawa M, Tomita H, Tanimoto K, Fujimoto S. Nationwide survey shows that methicillin-resistant Staphylococcus aureus strains heterogeneously and intermediately resistant to vancomycin are not disseminated throughout Japanese hospitals. J Clin Microbiol 39: 4445-4451 (2001)

10. Piao C, Karasawa T, Totsuka K, Uchiyama T, Kikuchi K. Prospective surveillance of community-onset and healthcare-associated methicillin-resistant Staphylococcus aureus isolated from a university-affiliated hospital in Japan. Microbiol Immunol 49: 959-970 (2005)
11. Goh SH, Byrne SK, Zhang JL, Chow AW. Molecular typing of Staphylococcus aureus on the basis of coagulase gene polymorphisms. J Clin Microbiol 30: 1642-1645 (1992)

12. Tsuchizaki N, Ishikawa J, Hotta K. Colony PCR for rapid detection of antibiotic resistance genes in MRSA and enterococci. Jpn J Antibiot 53: 422-429 (2000)

13. Daigle DM, Hughes DW, Wright GD. Prodigious substrate specificity of $\mathrm{AAC}\left(6^{\prime}\right)-\mathrm{APH}\left(2^{\prime \prime}\right)$, an aminoglycoside antibiotic resistance determinant in enterococci and staphylococci. Chem Biol 6: 99-110 (1999)

14. Nada T, Ichiyama S, Osada Y, Ohta M, Shimokata K, Kato $\mathrm{N}$, Nakashima N. Comparison of DNA fingerprinting by PFGE and PCR-RFLP of the coagulase gene to distinguish MRSA isolates. J Hosp Infect 32: 305-317 (1996)

15. Hookey JV, Richardson JF, Cookson BD. Molecular typing of Staphylococcus aureus based on PCR restriction fragment length polymorphism and DNA sequence analysis of the coagulase gene. J Clin Microbiol 36: 1083-1089 (1998)

16. Ida T, Okamoto R, Shimauchi C, Okubo T, Kuga A, Inoue M. Identification of aminoglycoside-modifying enzymes by susceptibility testing: epidemiology of methicillin-resistant Staphylococcus aureus in Japan. J Clin Microbiol 39: 3115-3121 (2001) 